\title{
Mass-spectrometric identification of primary biological particle markers and application to pristine submicron aerosol measurements in Amazonia
}

\author{
J. Schneider ${ }^{1}$, F. Freutel ${ }^{1}$, S. R. Zorn ${ }^{1,2}$, Q. Chen ${ }^{2}$, D. K. Farmer ${ }^{3}$, J. L. Jimenez ${ }^{3}$, S. T. Martin ${ }^{2}$, P. Artaxo ${ }^{4}$, \\ A. Wiedensohler ${ }^{5}$, and S. Borrmann ${ }^{1,6}$ \\ ${ }^{1}$ Particle Chemistry Department, Max Planck Institute for Chemistry, Mainz, Germany \\ ${ }^{2}$ School of Engineering and Applied Sciences and Department of Earth and Planetary Sciences, Harvard University, \\ Cambridge, MA, USA \\ ${ }^{3}$ Dept. of Chem. \& Biochem. \& CIRES, University of Colorado, Boulder, CO, USA \\ ${ }^{4}$ Applied Physics Department, Institute of Physics, University of São Paulo, Brazil \\ ${ }^{5}$ Leibniz Institute for Tropospheric Research, Leipzig, Germany \\ ${ }^{6}$ Institute for Atmospheric Physics, Johannes Gutenberg University Mainz, Germany
}

Received: 31 May 2011 - Published in Atmos. Chem. Phys. Discuss.: 5 July 2011

Revised: 21 October 2011 - Accepted: 6 November 2011 - Published: 17 November 2011

\begin{abstract}
The detection of primary biological material in submicron aerosol by means of thermal desorption/electron impact ionization aerosol mass spectrometry was investigated. Mass spectra of amino acids, carbohydrates, small peptides, and proteins, all of which are key building blocks of biological particles, were recorded in laboratory experiments. Several characteristic marker fragments were identified. The intensity of the marker signals relative to the total organic mass spectrum allows for an estimation of the content of primary biological material in ambient organic aerosol. The developed method was applied to mass spectra recorded during AMAZE-08, a field campaign conducted in the pristine rainforest of the central Amazon Basin, Brazil, during the wet season of February and March 2008. The low abundance of identified marker fragments places upper limits of $7.5 \%$ for amino acids and $5.6 \%$ for carbohydrates on the contribution of primary biological aerosol particles (PBAP) to the submicron organic aerosol mass concentration during this time period. Upper limits for the absolute submicron concentrations for both compound classes range from 0.01 to $0.1 \mu \mathrm{g} \mathrm{m}^{-3}$. Carbohydrates and proteins (composed of amino acids) make up for about two thirds of the dry mass of a biological cell. Thus, our findings suggest an upper limit for the PBAP mass fraction of about $20 \%$ to the submicron organic aerosol measured in Amazonia during AMAZE-08.
\end{abstract}

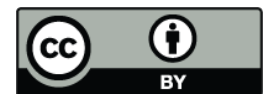

Correspondence to: J. Schneider (johannes.schneider@mpic.de)

\section{Introduction}

Primary biological aerosol particles (PBAP) are suggested to play an important role in atmospheric aerosol processes and cloud formation (Jaenicke, 2005; Jaenicke et al., 2007; Möhler et al., 2007; Deguillaume et al., 2008; Spracklen et al., 2010). Average number fractions of about $30 \%$ have been reported even in the fine mode aerosol, for aerodynamic particle diameters $\left(d_{\text {aero }}\right)$ between $400 \mathrm{~nm}$ and $1 \mu \mathrm{m}$ (Matthias-Maser and Jaenicke, 1995). Primary biological particles in the submicron fraction are expected to be mainly bacteria or viruses, e.g. Hinds (1999). Bacteria are typically rod-shaped, about $1-3 \mu \mathrm{m}$ long and $0.3-0.5 \mu \mathrm{m}$ wide (Morris et al., 2004). Size distribution measurements by Möhler et al. (2008) using mobility and aerodynamic particle sizing have shown that a large fraction of such airborne bacteria is found in the submicron mode. Pollen and fungal spores are generally larger than $1 \mu \mathrm{m}$ (Jones and Harrison, 2004; Elbert et al., 2007; Huffman et al., 2010), although pollen fragments are also present in the submicron range (Taylor et al., 2002, 2004). Furthermore, vegetative detritus has been reported as a constituent of PBAP (Rogge et al., 1993), but this contribution is considered to be minor in the submicron fraction. The dry mass of a typical bacterial cell contains about $55 \%$ proteins and amino acids, $24 \%$ nucleic acids, $10 \%$ carbohydrates, $7 \%$ lipids, and $5 \%$ inorganic minerals and trace elements (Watson et al., 2007). Mammal cells contain similar amounts of proteins and carbohydrates $(68 \%$ and $8 \%$, respectively), lower amounts of nucleic acids (5\%), but

Published by Copernicus Publications on behalf of the European Geosciences Union. 
higher amounts of lipids (19\%) (Munk, 2000). The variation found in pollen composition is larger: the dry mass of pollen contains between 10 and $40 \%$ proteins and 13-55\% carbohydrates (Campos et al., 2008). Viruses contain only proteins and nucleic acids (Beyer and Walter, 1988). Since proteins are composed of large chains of amino acids, on average amino acids and carbohydrates contribute about 60 to $80 \%$ to the dry mass of a biological cell.

Although it has been demonstrated in laboratory experiments (Diehl et al., 2001, 2002; von Blohn et al., 2005; Iannone et al., 2011) and field studies (Pratt et al., 2009) that PBAP can act as efficient ice nuclei (IN), model studies indicate that on a global scale PBAP account for less than one percent of the global IN fraction, while dust $(>80 \%)$ and soot dominate the IN (Hoose et al., 2010). In regions that are only to a small degree influenced by mineral dust and anthropogenic emissions, PBAP are expected to be of higher importance. One such region is the Amazonian rainforest (Prenni et al., 2009). Submicron PBAP would contribute significantly to the amount of IN because such small particles are efficiently transported to higher altitudes where temperatures are low enough to allow for ice formation. Another important effect is that PBAP for certain meteorological conditions can take up enough water to act as "giant" cloud condensation nuclei. Such "giant" CCN generate larger drops that fall faster than drops formed from smaller CCN, thereby facilitating coalescence and warm rain formation (Möhler et al., 2007). They may also limit the potential supersaturation and thus cloud activation of smaller particles by enhanced water depletion. Furthermore, PBAP play a significant role (about $13 \%$ ) in the deposition of phosphorus on a global scale (Mahowald et al., 2008; Spracklen et al., 2010). PBAP in Amazonia are reviewed in Martin et al. (2010b).

The Amazonian Aerosol Characterization Experiment 2008 (AMAZE-08) field campaign (Martin et al., 2010a) was conducted in the wet season from February to March 2008 in the Amazonian rainforest, Brazil. The objective of AMAZE08 was to improve our understanding of aerosol sources and aerosol-cloud interactions in the pristine Amazonian rainforest. One of the research foci was the assessment of the contribution of PBAP to the total aerosol, both in number fraction and mass fraction. The ability of PBAP to act as ice nuclei in the Amazonian rainforest during AMAZE-08 has been shown by Prenni et al. (2009), with observed IN number concentrations on the order of 1-2 per liter. They report that at temperatures above $-25^{\circ} \mathrm{C}$, biological particles seem to dominate IN by number. Further measurements performed during AMAZE-08 using the UV-APS (Ultra-Violet Aerodynamic Particle Sizer) technique show that PBAP are frequently found in the supermicron size range (Pöschl et al., 2010; Huffman et al., 2011). Similar findings have been reported from the Cooperative LBA Airborne Regional Experiment (CLAIRE-2001) experiments (Graham et al., 2003a, b). Nevertheless, it could be possible that also the fraction of PBAP in the submicron size range is of importance, because the pristine rainforest of the central Amazon Basin is only slightly influenced by anthropogenic emissions, especially in the wet season.

Laser-ablation single-particle aerosol mass spectrometry has been used in the past to identify PBAP. Czerwieniec et al. (2005) identified fragments of amino acids like glycine, proline, valine, threonine, leucine, isoleucine, histidine, and phenylalanine in positive ion mass spectra from cells and spores of Bacillus atrophaeus. Fergenson et al. (2004) detected glutamic acid in negative ion mass spectra of Bacillus atrophaeus and Bacillus thuringiensis. Furthermore, phosphorus was identified in negative ion mass spectra, suggesting its use as a well-suited marker for bioaerosol because phosphates occur in endospore nucleic acids, adenosine diand triphosphates, and cell membranes (Fergenson et al., 2004). Russell et al. (2004) studied the behavior of small peptides composed of glycine, arginine, and tyrosine and were able to explain the observed peaks by fragmentation of the amino acid molecules. Another widely used type of aerosol mass spectrometer (Aerodyne Aerosol Mass Spectrometer, AMS) (Canagaratna et al., 2007) is based on thermal desorption and electron ionization (EI), but so far it has not been applied systematically to biological material. Although electron ionization produces different fragmentation patterns than laser ablation, there are still many similarities in the spectra of organic species from both techniques (Silva and Prather, 2000). Identification of amino acids and amino acid fragments from peptides has been demonstrated using EI (Spiteller (1966), and references therein). Thus, we expect to be able to identify marker fragments from laboratory measurements of amino acids and to apply those markers to ambient aerosol data. Yttri et al. (2007) demonstrated that sugars, including fructose, glucose, sucrose, and trehalose, as well as sugar alcohols, such as arabitol, inositol, and mannitol, may represent important constituents of the water-soluble organic carbon fraction in the ambient aerosol and can be useful as tracers for PBAP. Therefore, we also investigated carbohydrates as possible marker fragments for PBAP.

This work describes a method to detect PBAP in the ambient atmosphere by using marker fragments for amino acids and carbohydrates. In the laboratory, mass spectra of particles produced from a selection of amino acids, carbohydrates (sugars), peptides, and proteins were recorded, and marker fragments for PBAP were identified. We introduce a scaling factor that allows for estimation of the quantitative contribution of PBAP to ambient organic aerosol. The method is applied to ambient data recorded in Amazonia during AMAZE-08. 
Table 1. Amino acids analyzed in the laboratory.

\begin{tabular}{|c|c|c|c|}
\hline Substance & Formula & Structure & $\begin{array}{c}\text { Molecular } \\
\text { weight }\left(\mathrm{g} \mathrm{mol}^{-1}\right)\end{array}$ \\
\hline Alanine $^{1}$ & $\mathrm{C}_{3} \mathrm{H}_{7} \mathrm{NO}_{2}$ & & 89.10 \\
\hline Cysteine $^{2}$ & $\mathrm{C}_{3} \mathrm{H}_{7} \mathrm{NO}_{2} \mathrm{~S}$ & & 121.16 \\
\hline Glutamic acid ${ }^{3}$ & $\mathrm{C}_{5} \mathrm{H}_{9} \mathrm{NO}_{4}$ & & 147.13 \\
\hline Glycine $^{4}$ & $\mathrm{C}_{2} \mathrm{H}_{5} \mathrm{NO}_{2}$ & & 75.07 \\
\hline Leucine $^{5}$ & $\mathrm{C}_{6} \mathrm{H}_{13} \mathrm{NO}_{2}$ & & 131.18 \\
\hline Proline $^{1}$ & $\mathrm{C}_{5} \mathrm{H}_{9} \mathrm{NO}_{2}$ & & 115.13 \\
\hline Tryptophan ${ }^{1}$ & $\mathrm{C}_{11} \mathrm{H}_{12} \mathrm{~N}_{2} \mathrm{O}_{2}$ & & 204.23 \\
\hline Valine $^{1}$ & $\mathrm{C}_{5} \mathrm{H}_{11} \mathrm{NO}_{2}$ & & 117.15 \\
\hline $\begin{array}{l}\text { Glutathione }^{1} \\
\text { (tripeptide) }\end{array}$ & $\mathrm{C}_{10} \mathrm{H}_{17} \mathrm{~N}_{3} \mathrm{O}_{6} \mathrm{~S}$ & & 307.33 \\
\hline
\end{tabular}

Manufacturer: ${ }^{1}$ Roth, ${ }^{2}$ Sigma Aldrich, ${ }^{3}$ Acros Organics, ${ }^{4}$ Merck, ${ }^{5}$ Fluka; Purity: $\geq 97 \%$.

\section{Measurements}

\subsection{Experimental identification of marker fragments in laboratory measurements}

The laboratory measurements were performed at the Max Planck Institute for Chemistry (MPIC), Mainz (Freutel, 2009). Typical constituents found in biological cells (amino acids, peptides, proteins, and carbohydrates) were analyzed by aerosol mass spectrometry. The compounds were individually dissolved in demineralized water and nebulized with an atomizer (TSI 3075). The particles were dried by diffusion, size selected by a Differential Mobility Analyzer (DMA; Grimm 5.5-900 or TSI 3080), and introduced into a timeof-flight aerosol mass spectrometer (Aerodyne Inc., compact C-ToF-AMS (Drewnick et al., 2005), or high-resolution HRToF-AMS (DeCarlo et al., 2006)). Both instruments operate with thermal desorption at $600^{\circ} \mathrm{C}$ and electron impact ion- ization. They differ only in the type of mass spectrometer: The HR-ToF-AMS provides a higher mass resolving power $\mathrm{m} / \Delta m$ (in "V-mode" typically 2000 at $\mathrm{m} / z 100$ compared to the C-ToF-AMS that has $m / \Delta m$ of about 800 at $m / z 100$ (DeCarlo et al., 2006)). While most compounds were measured using the C-ToF-AMS, the HR-ToF-AMS was used for the measurements of glutathione and levoglucosan.

A list of investigated amino acids is provided in Table 1. From the 20 proteinogenic amino acids (Beyer and Walter, 1988; Munk, 2000), we selected glycine as the simplest amino acid, three amino acids (alanine, valine, leucine) with aliphatic side chains as another important category of compounds, as well as other compounds representing additional classes: one sulfur-containing amino acid (cysteine), one with an aliphatic side chain and a second carboxyl group (glutamic acid), one aromatic amino acid (tryptophane), and proline, whose amino group is part of an aliphatic ring. Glutathione, a tripeptide composed of glutamic acid, cysteine, 
Table 2. Carbohydrates investigated in the laboratory.

\begin{tabular}{|c|c|c|c|}
\hline Substance & Formula & Structure & $\begin{array}{c}\text { Molecular } \\
\text { weight }\left(\mathrm{g} \mathrm{mol}^{-1}\right)\end{array}$ \\
\hline Glucose $^{1}$ & $\mathrm{C}_{6} \mathrm{H}_{12} \mathrm{O}_{6}$ & & 180.16 \\
\hline Glycogen ${ }^{1}$ & $<\left(\mathrm{C}_{6} \mathrm{H}_{10} \mathrm{O}_{5}\right)_{\mathrm{n}}$ & & $10^{6}-10^{7}$ \\
\hline Levoglucosan ${ }^{2}$ & $\mathrm{C}_{6} \mathrm{H}_{10} \mathrm{O}_{5}$ & & 162.14 \\
\hline Mannitol $^{3}$ & $\mathrm{C}_{6} \mathrm{H}_{14} \mathrm{O}_{6}$ & & 182.17 \\
\hline Saccharose $^{1}$ & $\mathrm{C}_{12} \mathrm{H}_{22} \mathrm{O}_{11}$ & & 342.30 \\
\hline
\end{tabular}

Manufacturer: ${ }^{1}$ Roth, ${ }^{2}$ Fluka, ${ }^{3}$ Alfa Aesar.

and glycine, was used as an example of a small peptide. In addition to the compounds listed in Table 1 , insulin (51 amino acids, molecular weight $\mathrm{MW} \approx 4700 \mathrm{~g} \mathrm{~mol}^{-1}$ ) and casein (169-209 amino acids, MW $\approx 19000-25000 \mathrm{~g} \mathrm{~mol}^{-1}$ ) were selected as examples for proteins.

The five carbohydrates that were investigated are listed in Table 2. We selected a monosaccharide (glucose), a disaccharide (saccharose, composed of glucose and fructose), and a polysaccharide (glycogen) composed of up to 50000 glucose units. As an example, we selected mannitol as a sugar alcohol, which is a component of fungal spores (Elbert et al., 2007). Levoglucosan, an anhydride of glucose, was also investigated. Levoglucosan is a pyrolysis product of cellulose and is a commonly used tracer for biomass burning aerosol (Simoneit et al., 1999; Fraser and Lakshmanan, 2000).

For each experiment, a blank gas phase measurement using a particle filter was recorded. This blank spectrum was later subtracted from the recorded mass spectrum of each compound to remove signals originating from the gas phase. This method avoids any uncertainties that can arise from ion fragmentation and attribution of these fragments to the various components of the gas phase and the particle phase, as is usually done by applying a fragmentation table (Allan et al., 2004) in the standard AMS analysis software (SQUIRREL v1.49, PIKA v1.08, see http://cires.colorado.edu/jimenez-group/wiki/index.php/ ToF-AMS_Analysis_Software and DeCarlo et al., 2006). The mass spectra represent averages over several minutes, corresponding to a number of sampled particles in the order of $10^{5}$.

Certain marker fragments for the compound classes amino acids and carbohydrates were identified. These markers are presented and discussed in Sect. 3.1. The fraction of the marker fragments to the total mass spectrum of the examined compounds has been found to be approximately constant for each compound class and is used in this study as a scaling factor SF, allowing for a quantification of the fractional contribution of the compound class to the total organic aerosol mass.

\subsection{Field measurements during AMAZE-08}

The field measurements were performed between 7 February and 14 March 2008 during AMAZE-08 (Martin et al., 
2010a). The principal measurement site of AMAZE-08 was tower TT34 $\left(02^{\circ} 35.675^{\prime} \mathrm{S}, 060^{\circ} 12.557^{\prime} \mathrm{W}, 110 \mathrm{~m}\right.$ a.s.l. $)$. It was located in the central Amazon Basin, $60 \mathrm{~km} \mathrm{NNW}$ of downtown Manaus and $40 \mathrm{~km}$ from the metropolis margins. The aerosol was sampled through an inlet with a $7.7 \mu \mathrm{m}$ cutoff at the top of the tower at a height of $38 \mathrm{~m}$. The sample line was designed to provide laminar flow conditions and the temperature of the flow was kept at $32{ }^{\circ} \mathrm{C}$ down to the container to avoid condensation in the pipe below the canopy. On top of the measurement container, the sampled air was dried to $30-40 \%$ relative humidity using an automatic regenerative dryer (Tuch et al., 2009) and then distributed to various instruments inside the air-conditioned container. For a complete overview of the measured parameters during AMAZE08 the reader is referred to Martin et al. (2010a).

The ambient data reported here were recorded with an Aerodyne HR-ToF-AMS that was operated in V-mode (DeCarlo et al., 2006). It was equipped with the first prototype of a high pressure inlet lens designed to transmit larger particles compared to the standard aerodynamic lens of the AMS, which has a $50 \%$ cutoff at $640 \mathrm{~nm} d_{\mathrm{va}}$ (vacuum aerodynamic diameter) as reported by Liu et al. (2007). Characterization measurements of the prototype showed that this design was only partly successful, since the $50 \%$ cutoff at about $800 \mathrm{~nm}$ $d_{\mathrm{va}}$ was only slightly larger than that of the standard lens.

Comparative measurements with a co-located HR-ToFAMS (operated by Harvard) (Chen et al., 2009) show that the data recorded by both instruments agreed to about $10 \%$ in the overlap region (Fig. 1, after Pöschl et al., 2010). The high pressure lens had slightly more transmission at larger particle diameters $\left(>500 \mathrm{~nm} d_{\mathrm{va}}\right)$ but a lower transmission for particles smaller than $260 \mathrm{~nm} d_{\mathrm{va}}$. This difference led to a lower reported total submicron aerosol mass by the MPIC instrument compared to the Harvard instrument because a higher fraction of aerosol mass resided between $100-300 \mathrm{~nm}$ than between $500-1000 \mathrm{~nm}$. The objective of the measurements using the high pressure inlet system was to detect primary biological material that is usually expected to be found at larger particle sizes. Thus, for the present analysis the lower transmission for smaller particles is not an issue. The (slightly) higher transmission for larger particles increases the probability to detect PBAP.

The AMS data were analyzed using the standard AMS analysis software (SQUIRREL v1.49, PIKA v1.08). Specific details of the data evaluation are listed in the Supplement.

In order to evaluate the high-resolution mass spectra that are needed to identify the exact marker peaks, the mass spectra were averaged over $12 \mathrm{~h}$ (06:00-18:00 and 18:00-06:00, local time). This averaging was necessary to sufficiently reduce the noise of the signal to allow for high-resolution peak fitting. The chosen time intervals also allow for a day to night differentiation. The cumulative peaks as identified from the laboratory data (Sect. 3.1) were fitted by a selection of exact $\mathrm{m} / \mathrm{z}$ that contribute most likely to the cumulative peak, including the respective marker peak. Thus, the relative con-

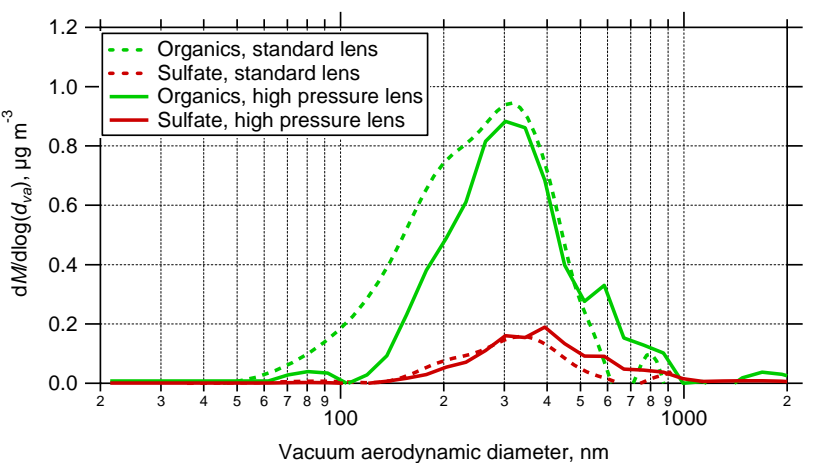

Fig. 1. Size distributions measured during AMAZE-08 by the two co-located HR-ToF-AMS instruments (Pöschl et al., 2010). The Harvard AMS used the standard lens, the MPIC AMS used a prototype of the "high pressure lens". The "high pressure lens" provided slightly higher transmission for particle sizes $>500 \mathrm{~nm} d_{\mathrm{va}}$.

tribution of the respective marker peak to the respective cumulative peak was inferred. The fraction of only this portion of the cumulative peak to the total organic aerosol signal was then calculated. In this way, the mass fraction of the marker peaks to the total organic aerosol was calculated with $12 \mathrm{~h}$ time resolution. For application to ambient data, it has to be considered that other compounds might also contribute to the marker fragments, thus background values have to be subtracted, in case such background values are available. Using the respective scaling factors derived from the laboratory results and appropriate background values for the marker fragments, the data can be converted into fractions of the organic mass concentration as follows:

fraction $=\mathrm{SF}_{\text {class }} \sum_{i}\left(f_{i}-f_{i}^{\text {background }}\right)$

where $\mathrm{SF}_{\text {class }}$ is the scaling factor for the two compound classes (amino acids and carbohydrates; see Fig. 3 and Sect. 3.1), $i$ denotes the respective $m / z, f_{i}$ is the ratio of the respective marker fragment signal intensity to the total organic signal, and $f_{i}^{\text {background }}$ represents the respective ratio from other sources contributing to the marker fragments.

\section{Results}

\subsection{Identified marker fragments}

\subsubsection{Amino acids and glutathione}

The mass spectra of the examined amino acids and of the tripeptide glutathione (Table 1) are displayed in Fig. 2. The observed $\mathrm{m} / \mathrm{z}$ can be explained by fragmentation of molecular sub-structures. The most important fragmentation mechanism is the loss of the $\mathrm{COOH}$ group (nominal $\mathrm{m} / \mathrm{z}, 45$, exact $m / z$ 44.997), leading to a dominant signal at $m / z=M-45$, where $M$ is the molar mass of the original molecule. 

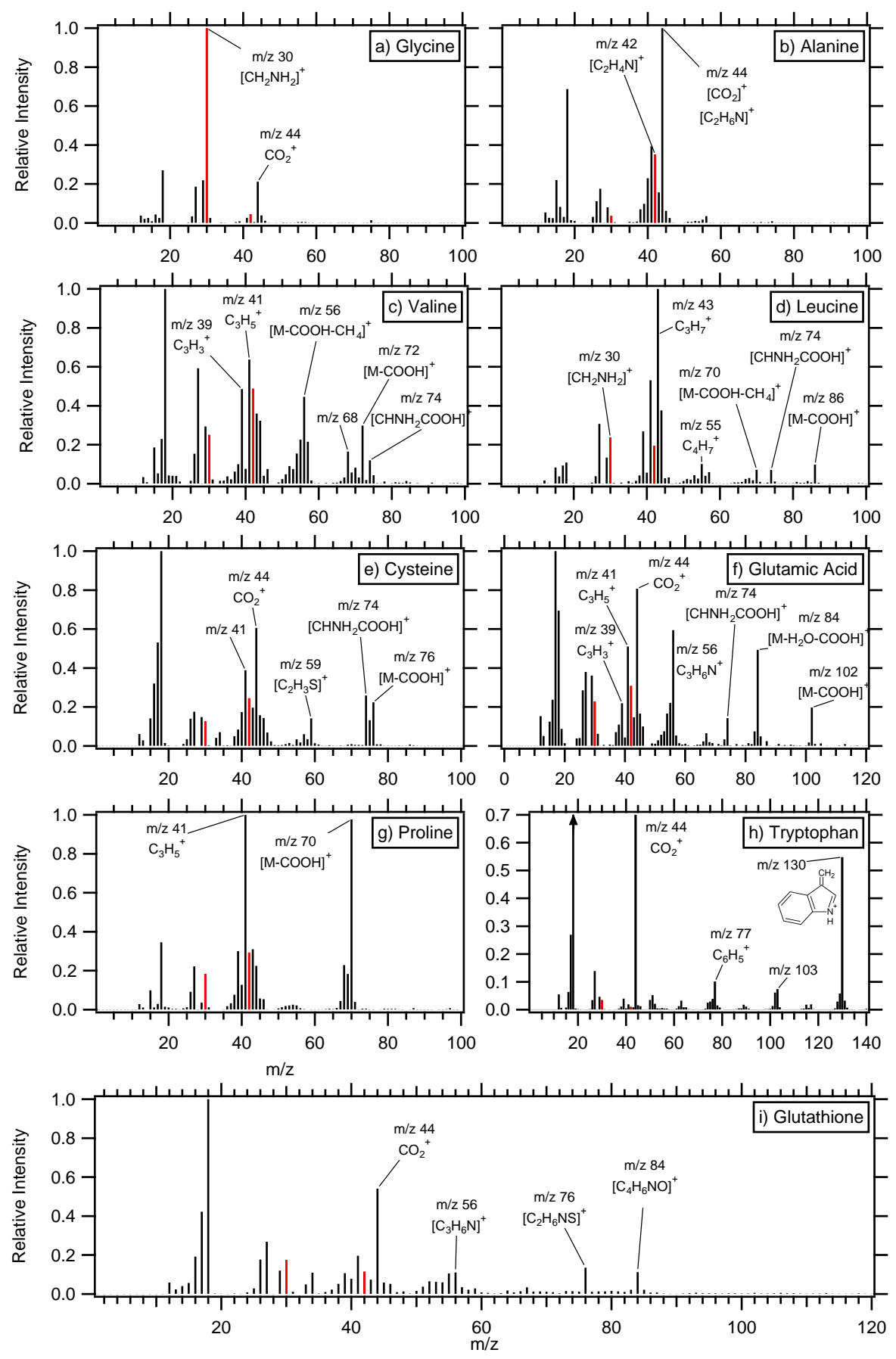

Fig. 2. Laboratory mass spectra from amino acid particles. The signals of identified marker fragments $(\mathrm{m} / \mathrm{z}, 30$ and 42$)$ are highlighted in red. Certain identified fragments are labeled.

Glycine, as the simplest amino acid $\left(\mathrm{C}_{2} \mathrm{H}_{5} \mathrm{NO}_{2}\right)$, shows a very clear fragmentation pattern. The carboxyl group $\mathrm{COOH}$ is lost from the molecule or molecular ion, leading to the $\mathrm{CH}_{4} \mathrm{~N}^{+}$ion at $m / z, 30$. The molecular ion signal $(\mathrm{m} / \mathrm{z}, 75)$ is also visible. Additional observed ions are $\mathrm{CO}_{2}^{+}$, as is typical of carboxylic acid detection in the AMS (e.g. Duplissy et al., 2011), and $\mathrm{H}_{2} \mathrm{O}^{+}\left(\mathrm{m} / \mathrm{z}, 44\right.$ and 18). The $\mathrm{H}_{2} \mathrm{O}^{+}$ion can origi- nate from decomposition of the molecule itself but also from molecular water present in the particles due to incomplete drying.

For alanine $\left(\mathrm{MW}=89.10 \mathrm{~g} \mathrm{~mol}^{-1}\right)$, the loss of the $\mathrm{COOH}$ group mainly leads to $\mathrm{C}_{2} \mathrm{H}_{6} \mathrm{~N}^{+}$. This fragment has the same nominal mass to charge ratio as $\mathrm{CO}_{2}^{+}$, namely $\mathrm{m} / z 44$. Additionally, a pronounced signal at $m / z, 42\left(\mathrm{C}_{2} \mathrm{H}_{4} \mathrm{~N}^{+}\right)$is 


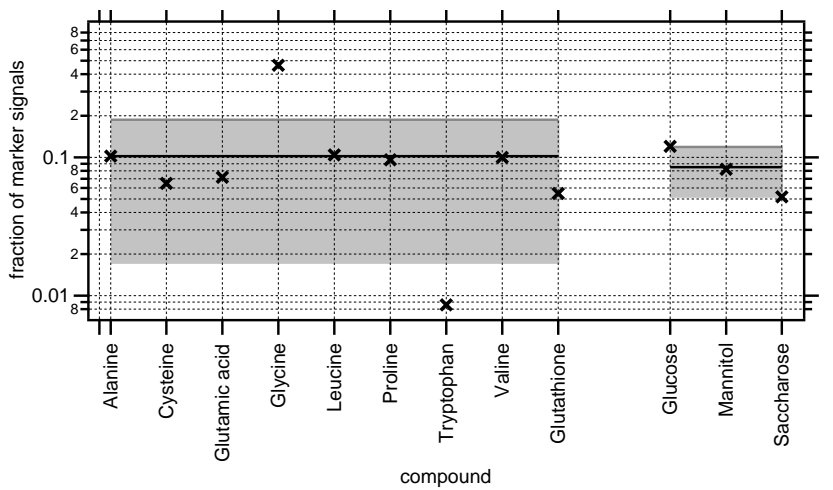

Fig. 3. Fraction of marker signals $(\mathrm{m} / \mathrm{z}, 30$ and 42 for amino acids and glutathione, $\mathrm{m} / \mathrm{z} 60,61$, and 73 for carbohydrates) in the mass spectra for the investigated amino acids, the tripeptide glutathione and the carbohydrates. Solid line: mean values (left: amino acids and glutathione without glycine and tryptophan, right: carbohydrates), shaded areas: standard deviation.

observed. Valine and leucine, the other two investigated aliphatic amino acids, have more complex mass spectra, with signals originating from the fragments $M-\mathrm{COOH}(\mathrm{m} / z, 72$ and 86, respectively) and $M-\mathrm{COOH}-\mathrm{CH}_{4}(\mathrm{~m} / z 56$ and 70$)$. The mass spectra of both compounds also show a signal at $m / z 74\left(\mathrm{CHNH}_{2} \mathrm{COOH}^{+}\right)$, which results from the loss of the aliphatic side chain. The signals at $\mathrm{m} / \mathrm{z}, 39,41$, and 43 can be explained by the loss of $\mathrm{CHNH}_{2}$ and $\mathrm{C}_{2} \mathrm{H}_{3} \mathrm{NH}_{2}$ from the $M$ $\mathrm{COOH}$ fragments at $\mathrm{m} / z, 72$ and 86 , forming $\mathrm{C}_{3} \mathrm{H}_{7}^{+}(\mathrm{m} / z 43)$, $\mathrm{C}_{3} \mathrm{H}_{3}^{+}(\mathrm{m} / \mathrm{z} 39)$ and $\mathrm{C}_{3} \mathrm{H}_{5}^{+}(\mathrm{m} / \mathrm{z} 41)$. Other pronounced ions are $\mathrm{CH}_{4} \mathrm{~N}^{+}(\mathrm{m} / \mathrm{z}, 30)$ and $\mathrm{C}_{2} \mathrm{H}_{4} \mathrm{~N}^{+}(\mathrm{m} / 2,42)$. Similar fragments $\left(M-\mathrm{COOH}, \mathrm{CH}_{4} \mathrm{~N}^{+}, \mathrm{C}_{2} \mathrm{H}_{4} \mathrm{~N}^{+}\right.$, and $\left.\mathrm{CHNH}_{2} \mathrm{COOH}^{+}\right)$ are observed in the mass spectrum of glutamic acid, with additional signals at $m / z, 56\left(\mathrm{C}_{3} \mathrm{H}_{6} \mathrm{~N}^{+}\right)$and $m / z, 84\left(M-\mathrm{H}_{2} \mathrm{O}\right.$ $\mathrm{COOH})$.

The amino group in the proline molecule is part of an aliphatic ring, leading to a stable ion with $m / z, 70\left(\mathrm{C}_{4} \mathrm{H}_{8} \mathrm{~N}^{+}\right)$ after loss of the $\mathrm{COOH}$ group. Further pronounced signals are found at $m / z 41\left(\mathrm{C}_{3} \mathrm{H}_{5}^{+}\right.$or $\mathrm{C}_{2} \mathrm{H}_{3} \mathrm{~N}^{+}$, not resolved by the C-ToF-AMS), $m / z 42\left(\mathrm{C}_{2} \mathrm{H}_{4} \mathrm{~N}^{+}\right)$, and $m / z 30\left(\mathrm{CH}_{4} \mathrm{~N}^{+}\right)$.

Tryptophan, as an example for an amino acid with an aromatic side chain, shows a different fragmentation pattern. Here, rather than $M-\mathrm{COOH}$ giving the most prominent signal (at high $m / z$ ), $M$-COOH- $\mathrm{CH}_{2} \mathrm{NH}$ forms as a very stable ion at $m / z 130\left(\mathrm{C}_{9} \mathrm{H}_{8} \mathrm{~N}^{+}\right.$, see Fig. 2h). Further fragmentation of this double ring leads to the phenyl ion $\left(\mathrm{C}_{6} \mathrm{H}_{5}^{+}, \mathrm{m} / z\right.$ 77) or the styrene-like cation $\left(\mathrm{C}_{8} \mathrm{H}_{7}^{+}, \mathrm{m} / z\right.$ 103). Additional large signals at $m / z, 18\left(\mathrm{H}_{2} \mathrm{O}^{+}\right)$and $m / z, 44\left(\mathrm{CO}_{2}^{+}\right)$are observed, while the signals at $m / z, 30\left(\mathrm{CH}_{4} \mathrm{~N}^{+}\right)$and $m / z, 42\left(\mathrm{C}_{2} \mathrm{H}_{4} \mathrm{~N}^{+}\right)$ are small.

Cysteine, a sulfur-containing amino acid, forms the fragments $M$ - $\mathrm{COOH}(\mathrm{m} / \mathrm{z}, 76)$ and $\mathrm{CHNH}_{2} \mathrm{COOH}^{+}(\mathrm{m} / z, 74)$. Additionally, signals due to sulfur-containing fragments (e.g. $\mathrm{C}_{2} \mathrm{HS}^{+}, m / z, 57 ; \mathrm{C}_{2} \mathrm{H}_{3} \mathrm{~S}^{+}, m / z$ 59) can be found (Fig. 2e), as well as the fragments at $m / z, 30$ and $m / z, 42$ that have been observed in the mass spectra of the other amino acids (see above).

The most frequently detected fragment $M-\mathrm{COOH}$ is not suitable as a general marker fragment of amino acids because it is at a different $\mathrm{m} / \mathrm{z}$ for each individual amino acid. The frequently occurring signal at $\mathrm{m} / z 74$, though possibly suitable for the identification of single amino acids, is not applicable to oligomeric peptides and proteins because after the formation of a peptide bond the $\mathrm{m} / \mathrm{z}, 74$ fragment is not to be expected any more. The nitrogen containing fragments $\mathrm{CH}_{4} \mathrm{~N}^{+}(\mathrm{m} / 2,30.0344)$ and $\mathrm{C}_{2} \mathrm{H}_{4} \mathrm{~N}^{+}(\mathrm{m} / \mathrm{z}, 42.0344)$ are the most common characteristic marker fragments. $\mathrm{CH}_{4} \mathrm{~N}^{+}$was also found to be a characteristic fragment in the mass spectra of peptides and amino acids, as obtained by laser ablation mass spectrometry (Russell et al., 2004). The fragment $m / z 56\left(\mathrm{C}_{3} \mathrm{H}_{6} \mathrm{~N}^{+}\right)$has been observed only for larger amino acids and is therefore not well suited as a general marker for amino acids. The fraction of the marker fragments $\mathrm{CH}_{4} \mathrm{~N}^{+}$ and $\mathrm{C}_{2} \mathrm{H}_{4} \mathrm{~N}^{+}$to the total mass spectrum of each of the examined amino acids is shown in Fig. 3. This fraction was found to be approximately constant $(0.085 \pm 0.020)$ for most of the investigated molecules. The inverse of this fraction is used in the present study as a scaling factor $\mathrm{SF}_{\mathrm{amino}}$. Glycine and tryptophan were not included in this average. For glycine, the loss of the $\mathrm{COOH}$ group yields the $\mathrm{CH}_{4} \mathrm{~N}^{+}$ion. The fraction of $\mathrm{m} / \mathrm{z} 30$ therefore is much higher for glycine than for other amino acids. Since the large fraction of $\mathrm{m} / \mathrm{z} 30$ is a feature expected only for glycine, including glycine here would likely overestimate $\mathrm{SF}_{\text {amino. Tryptophan is a hetero- }}$ aromatic amino acid with stable ring structures, inhibiting further fragmentation. Therefore, the fraction of the used marker fragments is significantly lower than for the other investigated amino acids. We assume here that the six other investigated amino acids are representative for the majority of the 20 proteinogenic amino acids. This assumption is justified, because glycine is the only amino acid where the loss of $\mathrm{COOH}$ leads to $\mathrm{m} / \mathrm{z} 30$, and there is only one additional hetero-aromatic proteinogenic amino acid similar to tryptophan, namely histidine (Beyer and Walter, 1988).

As an example for a small peptide (an oligomer of a limited number of amino acids), glutathione (a tripeptide consisting of glutamic acid, cysteine, and glycine) was analyzed (Fig. 2i). The most prominent signals are $\mathrm{m} / \mathrm{z} 84$ $\left(\mathrm{C}_{4} \mathrm{H}_{6} \mathrm{NO}^{+}\right)$, which is formed by loss of the glutamic acid side chain and a $\mathrm{COOH}$ group, leading to a stable ring structure; $m / z 76\left(\mathrm{C}_{2} \mathrm{H}_{6} \mathrm{NS}^{+}\right.$, the $M$ - $\mathrm{COOH}$ fragment of cysteine), $m / z 56\left(\mathrm{C}_{3} \mathrm{H}_{6} \mathrm{~N}^{+}\right), \mathrm{m} / \mathrm{z} 18$, and $\mathrm{m} / z$ 44. The above identified marker fragments $\mathrm{m} / \mathrm{z} 30$ and 42 are also found in the glutathione spectrum, with a similar fraction as for most investigated amino acids. 


\subsubsection{Proteins}

The mass spectra of the two investigated proteins (insulin and casein) are displayed in Fig. 4. Insulin, which is not soluble in pure water, was dissolved in diluted hydrochloric acid. The two corresponding signals from $\mathrm{H}^{35} \mathrm{Cl}^{+}$and $\mathrm{H}^{37} \mathrm{Cl}^{+}$are marked in grey. Insulin, a smaller protein, also shows amino acid fragments that can be identified as $M$ $\mathrm{COOH}$. For example, $\mathrm{m} / z 136$ can be identified as the fragment $M$-COOH from tyrosine $\left(\mathrm{MW}=181 \mathrm{~g} \mathrm{~mol}^{-1}\right), \mathrm{m} / z 120$ from phenylalanine $\left(\mathrm{MW}=165 \mathrm{~g} \mathrm{~mol}^{-1}\right), \mathrm{m} / z 110$ from histidine $\left(\mathrm{MW}=155 \mathrm{~g} \mathrm{~mol}^{-1}\right), \mathrm{m} / z 86$ from leucine, $\mathrm{m} / \mathrm{z} 72$ from valine, and $\mathrm{m} / \mathrm{z} 70$ from proline. Tyrosine, phenylalanine, and histidine are aromatic amino acids and thus their fragments $M-\mathrm{COOH}$ are expected to be very stable. Furthermore, the nitrogen-containing fragments that were also identified in many amino acid mass spectra $\left(\mathrm{m} / 2.56, \mathrm{C}_{3} \mathrm{H}_{6} \mathrm{~N}^{+}\right.$; $m / z, 42, \mathrm{C}_{2} \mathrm{H}_{4} \mathrm{~N}^{+}$; and $m / z 30, \mathrm{CH}_{4} \mathrm{~N}^{+}$) can be detected, although in a smaller fraction of the total organic mass spectrum (about 0.03) compared to the pure amino acids.

The mass spectrum of casein, a larger protein with a molar mass in the range of $19000-25000 \mathrm{~g} \mathrm{~mol}^{-1}$ is dominated by a large $\mathrm{CO}_{2}^{+}$peak at $\mathrm{m} / \mathrm{z}$ 44. A sodium hydroxide solution was added to dissolve the casein in water, which may increase the amount of $\mathrm{CO}_{2}^{+}$measured via formation of sodium carbonate. However, this was corrected for in a blank measurement of a neat sodium hydroxide solution. Thus, the high signal at $m / z, 44$ may indicate strong thermal decomposition of the molecule and possibly also oxidation of the fragments in the vaporization process of the mass spectrometer (Diesch, 2008). Apart from this dominant signal at $m / z 44$, some less intense signals were identified that were also detected in the amino acid mass spectra and/or in the mass spectrum of insulin. For example, the signal at $m / z, 70$ can be identified as the $M-\mathrm{COOH}$ fragment of proline, which is highly abundant in casein. The fragment at $m / z 91\left(\mathrm{C}_{7} \mathrm{H}_{7}^{+}\right)$was also detected in insulin, though not in any of the investigated amino acids. Casein contains only a relatively small amount of aromatic amino acids, and this fact might explain the low number of signals at higher $\mathrm{m} / \mathrm{z}$, as compared to insulin. Again, the marker fragments at $m / z, 42$ and $m / z, 30$ are detected. Their fraction of the total organic signal (without the high $\mathrm{m} / \mathrm{z} 44$ signal) is about 0.089 , thus very similar to the value found for the pure amino acids of $0.085 \pm 0.020$ (see above).

Although these results indicate that certain amino acid fragments can be found also in the mass spectra of proteins measured with the AMS, the complete evaporation of proteins within the AMS and their full quantification by the use of two amino acid marker fragments still has to be verified.

\subsubsection{Carbohydrates}

Glucose, saccharose, mannitol, levoglucosan, and glycogen were analyzed as examples for carbohydrates and their anhydrides (Table 2). The mass spectra are displayed in Fig. 5.
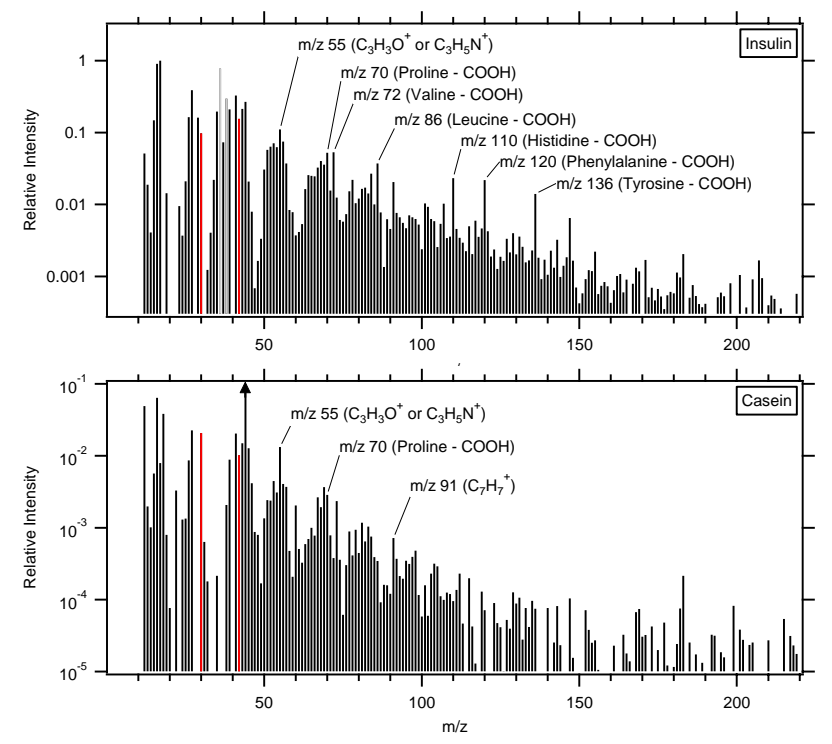

Fig. 4. Mass spectra of the two proteins investigated. The identified marker signals for amino acids $(\mathrm{m} / \mathrm{z} 30$ and 42) are highlighted (red). Selected identified fragments are labeled. Insulin was dissolved in $\mathrm{HCl}$, the corresponding signals $(\mathrm{m} / \mathrm{z}, 36$ and 38) are marked in grey.

Typical signals were found for the sequence $\mathrm{C}_{n} \mathrm{H}_{2 n+1} \mathrm{CO}^{+}$, with $n=0-2\left(\mathrm{CHO}^{+}, m / z 29 ; \mathrm{C}_{2} \mathrm{H}_{3} \mathrm{O}^{+}, m / z 43 ; \mathrm{C}_{3} \mathrm{H}_{5} \mathrm{O}^{+}\right.$, $m / z, 57$ ), as well as at $m / z, 44$ (with similar contributions by $\mathrm{CO}_{2}^{+}$and $\mathrm{C}_{2} \mathrm{H}_{4} \mathrm{O}^{+}$). These fragments are commonly found in AMS mass spectra of oxygenated organic compounds, limiting their usefulness as markers for carbohydrates (DeCarlo et al., 2006; Kroll et al., 2009; Sun et al., 2009). Better suited as marker fragments appear to be the ion fragments $\mathrm{C}_{2} \mathrm{H}_{4} \mathrm{O}_{2}^{+}\left(\mathrm{m} / z\right.$ 60.0211), $\mathrm{C}_{2} \mathrm{H}_{5} \mathrm{O}_{2}^{+}(\mathrm{m} / \mathrm{z}, 61.029)$, and $\mathrm{C}_{3} \mathrm{H}_{5} \mathrm{O}_{2}^{+}(\mathrm{m} / 2,73.029)$. Saccharose and glycogen (the disaccharide and the polysaccharide) show a prominent signal at $\mathrm{m} / z 85\left(\mathrm{C}_{4} \mathrm{H}_{5} \mathrm{O}_{2}^{+}\right)$, and the sugar alcohol mannitol shows a characteristic signal at $m / z 56\left(\mathrm{C}_{3} \mathrm{H}_{4} \mathrm{O}^{+}\right)$. The ions at $\mathrm{m} / z 60$ and 73 have been widely used previously as marker fragments for biomass-burning particles (Schneider et al., 2006; Alfarra et al., 2007; Lee et al., 2010), mainly because of the release of levoglucosan and related molecules during pyrolysis of cellulose (Simoneit et al., 1999; Fraser and Lakshmanan, 2000). Secondary organic material and fatty acids also form fragments at $\mathrm{m} / \mathrm{z} 60$ and 73 (Mohr et al., 2009). Thus, for an arbitrary mass spectrum, attribution of these fragments as markers for biomass burning, secondary organic material, or PBA particles cannot be uniquely determined. Nevertheless, the values inferred herein for the ambient spectra can be regarded as upper limits for PBAP carbohydrates.

To obtain a scaling factor for the quantification, we used only glucose, saccharose, and mannitol because levoglucosan is a primary tracer for biomass burning (see above). 

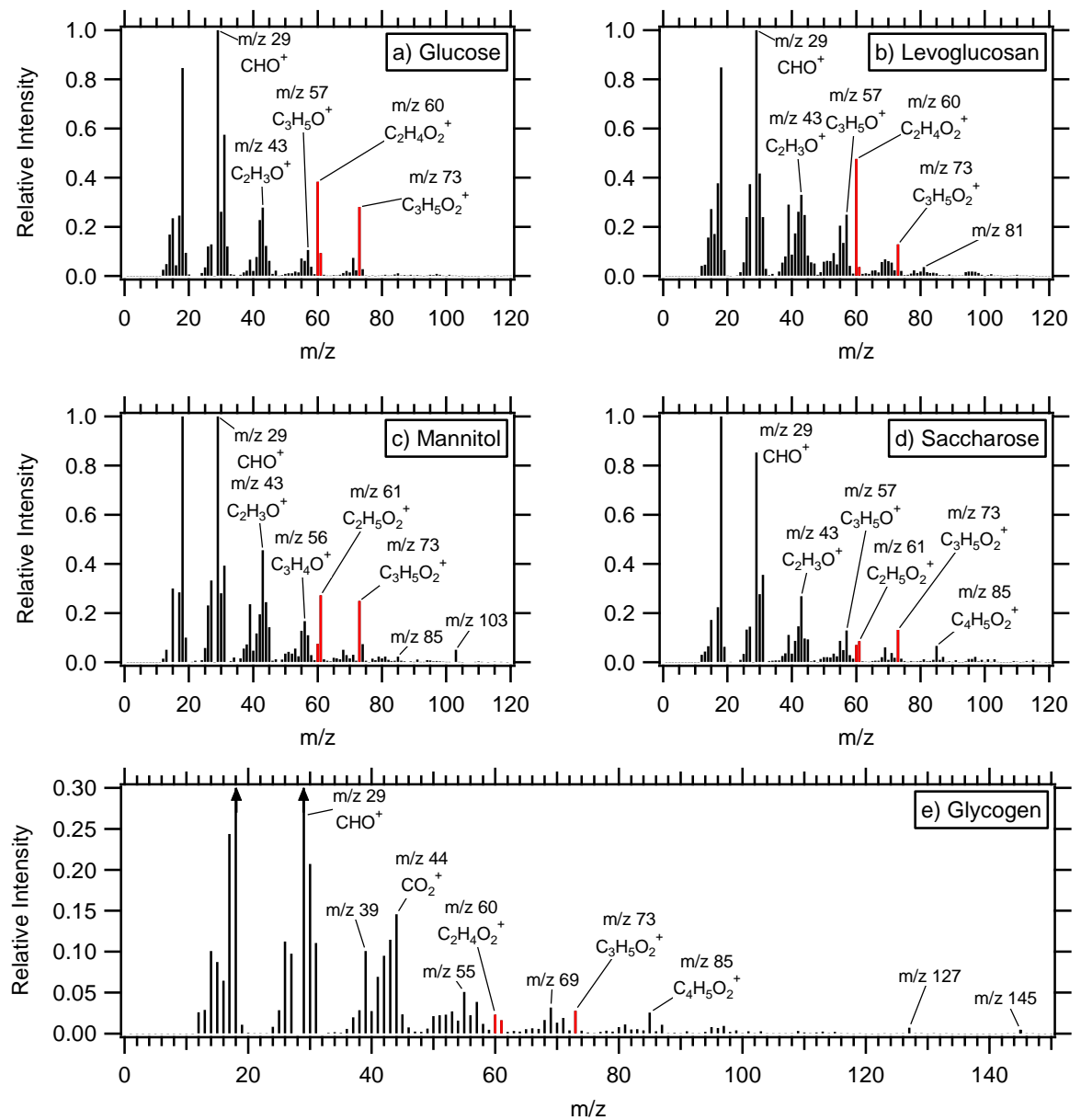

Fig. 5. Mass spectra of the carbohydrates investigated in the laboratory. The identified marker signals $(\mathrm{m} / \mathrm{z}, 60,61$, and 73$)$ are highlighted in red.

The large polymer glycogen was found to be less volatile on the AMS vaporizer than the mono- and disaccharides. The mean fraction of the common marker fragments $(\mathrm{m} / \mathrm{z} 60$, $\mathrm{m} / \mathrm{z} 61$, and $\mathrm{m} / \mathrm{z}$ 73) to the total mass spectrum of these three compounds was $0.085 \pm 0.034$ (mean and standard deviation, Fig. 3). The inverse of this fraction is used as a scaling factor $\mathrm{SF}_{\text {carbohydrate. }}$

\subsection{Results from the AMAZE-08 field campaign}

The time series of non-refractory submicron particle mass concentrations measured with the MPIC HR-ToF-AMS during the AMAZE-08 campaign is shown in Fig. 6. Approximately $72 \%$ of the detected non-refractory submicron particle mass was composed of organic matter, while about $26 \%$ was composed of ammonium and sulfate. Nitrate and chloride were found to be negligible. Slight differences to the values reported by Chen et al. (2009) from the colocated HR-ToF-AMS (Harvard) during AMAZE-08 can be explained by the different inlet transmission functions of the two mass spectrometers. The AMAZE-08 values are similar to the chemical composition of the fine mode $\left(d_{\text {aero }}<2 \mu \mathrm{m}\right)$ of CLAIRE-2001, an earlier campaign in the Amazon Basin. In CLAIRE-2001, $81 \%$ organics and $16 \%$ sulfate were reported for the non-refractory species composition, excluding black carbon and soil dust (Graham et al., 2003a). A detailed analysis of the organic fraction measured during AMAZE-08 with the co-located AMS in high-resolution mode has been presented by Chen et al. (2009). Their results show that local production of biogenic secondary organic aerosol dominated the submicron organic mass concentration during times with low sulfate to organic ratios. During times with a higher sulfate fraction, the influence of air masses arriving from out of the Amazon Basin increased, and the organic fraction was found to be more oxidized.

After averaging the high-resolution mass spectra over $12 \mathrm{~h}$ (06:00-18:00 and 18:00-06:00, local time), the following ion fragments were fitted to the cumulative marker peaks that were identified in Sect. 3.1: $\mathrm{m} / z$ 30: $\mathrm{NO}^{+}, \mathrm{CH}_{2} \mathrm{O}^{+}, \mathrm{CH}_{4} \mathrm{~N}^{+}$, $\mathrm{C}_{2} \mathrm{H}_{6}^{+} ; m / z, 42: \mathrm{C}_{2} \mathrm{H}_{2} \mathrm{O}^{+}, \mathrm{C}_{2} \mathrm{H}_{4} \mathrm{~N}^{+}, \mathrm{C}_{3} \mathrm{H}_{6}^{+} ; m / z$ 60: $\mathrm{CSO}^{+}$, 


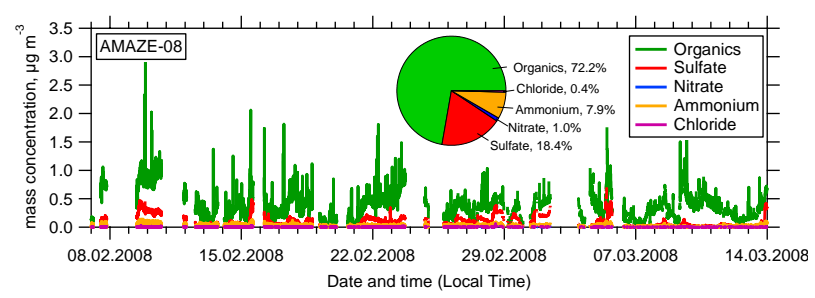

Fig. 6. Time series of non-refractory submicron particulate mass concentrations during AMAZE-08 measured by the AMS operating with the high pressure lens. Approximately $72 \%$ of the detected aerosol mass was composed of organic matter, while ammonium sulfate contributed about $26 \%$. Nitrate and chloride were found to be negligible. Measurement periods that were possibly influenced by local emission sources like vehicle exhaust, the exhaust of the on-site power generator, or regional anthropogenically polluted outflow from Manaus arriving at the sampling tower were excluded (Martin et al., 2010a).

$\mathrm{C}_{5}^{+}, \mathrm{C}_{2} \mathrm{H}_{4} \mathrm{O}_{2}^{+}, \mathrm{C}_{3} \mathrm{H}_{8} \mathrm{O}^{+} ; m / z 61: \mathrm{C}_{2} \mathrm{H}_{2} \mathrm{Cl}^{+}, \mathrm{C}_{5} \mathrm{H}^{+}, \mathrm{C}_{2} \mathrm{H}_{5} \mathrm{O}_{2}^{+}$; and $m / z$ 73: $\mathrm{C}_{6} \mathrm{H}^{+}, \mathrm{C}_{3} \mathrm{H}_{5} \mathrm{O}_{2}^{+}, \mathrm{C}_{3} \mathrm{H}_{9} \mathrm{Si}^{+}, \mathrm{C}_{4} \mathrm{H}_{9} \mathrm{O}^{+}$. Examples of the peak fitting are shown in Fig. 7.

Figure 8 shows the upper limits of the amino acid and carbohydrate fractions to the submicron organic aerosol. These data were calculated using (1), with the results of the peak fitting to the 12-h averaged mass spectra (Fig. S1) and the respective scaling factors from the laboratory data, as described in Sects. 2.2 and 3.1. Equation (1) includes the option to subtract a background value that accounts for contributions to the respective marker from other sources. Such other sources can be, e.g. biomass burning, which contributes to a significant fraction to $m / z$ 60. In a recent study, Cubison et al. (2011) observed a background value for $f_{60}^{\text {background }}$ of about $0.003 \pm 0.0006$ for urban areas without biomass burning influence. Additionally, secondary organic aerosol (SOA) may contribute to the marker ions as well. Chamber results showed values for $f_{60+61+73}$ of 0.004 and for $f_{30+42}$ of 0.002 for SOA produced by the photooxidation of isoprene, the ozonolysis of $\alpha$-pinene, and the ozonolysis of $\beta$-caryophyllene, all at low $\mathrm{NO}_{\mathrm{x}}$ concentration (Chen, 2011). However, it is not clear if the same background values can be applied to ambient air in a tropical rainforest. Another possible source for nitrogen-containing organic ions are amines which have been observed by AMS in urban studies (Aiken et al., 2009; Huffman et al., 2009; Sun et al., 2009). According to these studies amines produce the ionic fragments $\mathrm{C}_{3} \mathrm{H}_{8} \mathrm{~N}^{+}$ $(\mathrm{m} / \mathrm{z}, 58)$ and $\mathrm{C}_{5} \mathrm{H}_{12} \mathrm{~N}^{+}(\mathrm{m} / \mathrm{z}, 86)$, but also further fragmentation to $\mathrm{CH}_{4} \mathrm{~N}^{+}$is conceivable. Again, a background value of amines for a tropical rainforest is not known. Therefore, in the present study no background subtraction was applied, such that the reported values represent upper limits for the individual compound classes and therefore also for PBAP.

The time trend of the upper limit of the amino acid fraction (Fig. 8a) shows no diel pattern and remains rather constant, with the exception of two pronounced peaks on 28 February and 5 March. On average, the upper limit of the amino acid fraction is $7.5( \pm 2.3) \%$ (mean and standard deviation) of the total submicron organic mass concentration.

The upper limit of the carbohydrate fraction (Fig. 8b) at times shows a diel pattern, with higher values during night time, though this pattern is not consistent over the whole time series. However, the relative maximum values are always found during night time. This would agree with Elbert et al. (2007) who report larger concentrations of mannitol due to fungal emissions during night time in Amazonia. Another possibility would be the diel SOA pattern as shown by Chen et al. (2009), such that the PBAP fraction increases relative to the total organic aerosol mass. However, in this case also the amino acids should show the same diel pattern which they do not. The upper limit of the carbohydrate fraction is 5.6 $( \pm 1.1) \%$ (mean value and standard deviation). Separated into day and night, we obtain a mean daytime value of $5.3( \pm 1.0) \%$ and a mean nighttime value of $5.7( \pm 1.2) \%$, showing that there is no statistically significant difference within the one-sigma standard deviation between day and night.

The $f_{60}$ value in the present study is $0.0024 \pm 0.0042$. Comparing with the background value for $f_{60}^{\text {background }}$ reported by Cubison et al. (2011), $0.003 \pm 0.0006$, our value also implies that the fraction of fresh biomass burning aerosol to the submicron organic aerosol is low to negligible, as discussed in Chen et al. (2009).

During most of the time, the upper limit fractions of both amino acids and carbohydrates are within the shaded onesigma standard deviation area of the mean value in Fig. 8. However, the upper panel of Fig. 8 reveals that on 5 March a markedly higher upper limit fraction of amino acids was observed. This increase was not accompanied by an increase of the carbohydrate marker. The high resolution signals at $\mathrm{m} / \mathrm{z} 30$ and 42 are displayed in Fig. S2 in the Supplement, showing that the marker fragments $\mathrm{CH}_{4} \mathrm{~N}^{+}$and $\mathrm{C}_{2} \mathrm{H}_{4} \mathrm{~N}^{+}$ are clearly enhanced during this $12 \mathrm{~h}$ time period. The unit mass resolution spectrum does not show significant differences from the mass spectra during the previous or the following time periods. This event coincides with heavy rain during the afternoon (around 15:00 LT) of 5 March. It may be that the observed increase of amino acid markers is related to increased PBAP emissions triggered by the rain event. However, in this case also an increase of the carbohydrate markers would be expected. Enhanced wash-out of water soluble organic material (like carbohydrates or aged SOA) is unlikely, because the total organic mass concentration did not decrease during the rain event. Additionally we cannot rule out that the heavy rain event contaminated the sampling in some way. Thus, the reason for the high fraction of the amino acid markers on this day remains unresolved.

The upper limits of the absolute mass concentration of the marker compounds are shown in the lowest panel of 

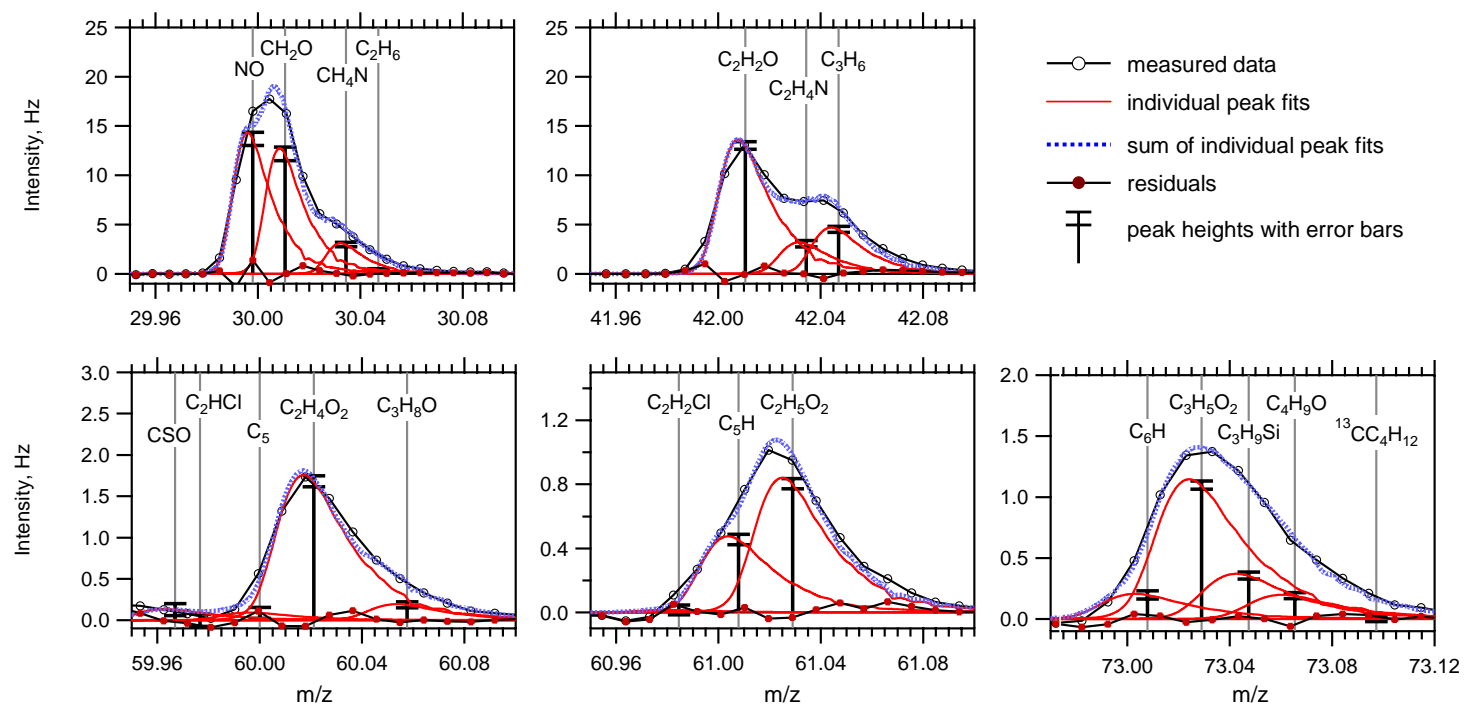

Fig. 7. Examples for the high-resolution peak fitting of the AMAZE-08 data, illustrating how the fractions of the marker peaks to the total unit mass resolution peaks were determined.
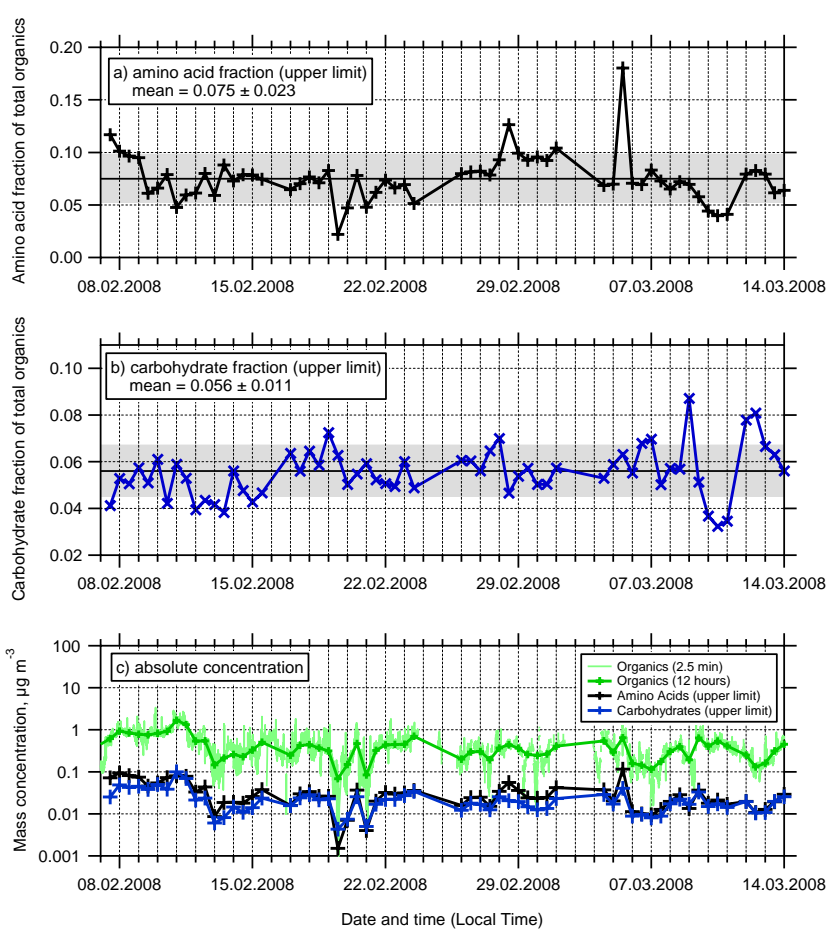

Fig. 8. Upper limits of the fractional abundances of amino acids (upper panel) and carbohydrates (middle panel) to the submicron organic aerosol mass concentration. Mean values: amino acids $7.5 \%$, carbohydrates $5.6 \%$. Lower panel: absolute concentrations of amino acids (upper limits), carbohydrates (upper limits) and total organics (in raw time resolution and as $12 \mathrm{~h}$ mean values).
Fig. 8, along with the mass concentration of the total submicron organic matter. Both the upper limit concentrations of amino acids and carbohydrates range from 0.01 to $0.1 \mu \mathrm{g} \mathrm{m}^{-3}$. The mean values and standard deviations are $0.029 \pm 0.021 \mu \mathrm{g} \mathrm{m}^{-3}$ and $0.022 \pm 0.016 \mu \mathrm{g} \mathrm{m}^{-3}$ for amino acids and carbohydrates, respectively. The fine mode concentrations of sugars, sugar alcohols, and anhydrosugars (including levoglucosan) measured during CLAIRE-2001 $\left(\sim 0.07 \mu \mathrm{g} \mathrm{m}^{-3}\right)$ are on the same order of magnitude though slightly higher (Graham et al., 2003b). The explanation may be that Graham et al. analyzed $\mathrm{PM}_{2.5}$ and therefore observed higher concentrations. Amino acids and proteins were not analyzed during CLAIRE-2001.

From the measurements of amino acids and carbohydrates we can estimate the total contribution of PBAP to the submicron aerosol. As stated above, literature values on the percentage of proteins in PBAP range between 10 and $70 \%$, on that of carbohydrates between 8 and $55 \%$. Although this is a wide range, it can be assumed that on average amino acids (in the form of proteins) and carbohydrates together account for about two third of a biological cell. Thus we can estimate that the sum of the inferred amino acid and carbohydrate percentages $(7.5 \%+5.6 \% \approx 13 \%)$ corresponds to an upper limit of the total contribution of PBAP to the submicron organic mass concentration of about $20 \%$ for the AMAZE-08 data. The uncertainties included in this upper limit include the probable overestimation of amino acids and carbohydrates because no applicable background value is available, the possible contribution of free amino acids (which are thought to originate from PBAP as well, Matsumoto and Uematsu, 2005), the uncertainties in the derived scaling factors, and the large variability in the composition of biological cells. 


\section{Summary and conclusions}

We presented a method to estimate the mass fraction of primary biological aerosol particles in ambient organic aerosol from aerosol mass spectrometer data. In laboratory studies, we identified a set of distinct marker fragments for amino acids and for carbohydrates as marker compounds for primary biological aerosol particles. Marker fragments found for amino acids were $\mathrm{CH}_{4} \mathrm{~N}^{+}(\mathrm{m} / \mathrm{z}, 30)$ and $\mathrm{C}_{2} \mathrm{H}_{4} \mathrm{~N}^{+}(\mathrm{m} / \mathrm{z}, 42)$ and for carbohydrates were $\mathrm{C}_{2} \mathrm{H}_{4} \mathrm{O}_{2}^{+}(\mathrm{m} / \mathrm{z} 60), \mathrm{C}_{2} \mathrm{H}_{5} \mathrm{O}^{+}$ $(\mathrm{m} / \mathrm{z}, 61)$, and $\mathrm{C}_{3} \mathrm{H}_{5} \mathrm{O}_{2}^{+}(\mathrm{m} / \mathrm{z}$ 73). Evaluation of these marker fragments in ambient data allowed for quantitative determination of upper limits for the concentration of these compounds. For carbohydrates, a caution is that carbohydrate anhydrides may also originate in part from biomass burning, especially levoglucosan, though for AMAZE-08 in particular these sources could be ruled out. Some of the marker ions, such as $m / z 60$ and 73, may also have contributions from other species, such as secondary organic material. Also for the amino acid markers, it cannot be ruled out that other compounds contribute to the marker fragments. Based on these considerations, our results for AMAZE-08 indicate that the upper limit fractional contribution to the total submicron organic aerosol mass concentration was approximately $7.5 \%$ for amino acids and $5.6 \%$ for carbohydrates. We estimate an upper limit of the total contribution of PBAP to the submicron organic mass concentration during AMAZE08 of about $20 \%$, although associated with large uncertainties. Furthermore, we can say that the contribution of fresh biomass burning was also low, as was already discussed by Chen et al. (2009). The upper limit for the absolute mass concentration of amino acids was $0.029 \pm 0.021 \mu \mathrm{g} \mathrm{m}^{-3}$, for carbohydrates it was $0.022 \pm 0.016 \mu \mathrm{g} \mathrm{m}^{-3}$.

Overall, our results are in agreement with findings reported from other studies during AMAZE-08, which concluded that the submicron organic aerosol is mainly of secondary origin and that PBAP are mostly found in the coarse mode (Chen et al., 2009; Pöschl et al., 2010), as well as with earlier field campaigns (Martin et al., 2010a). The upper limit sugar content of about $5.6 \%$ is in agreement with fine mode filter data reported by Graham et al. (2003b) in the Amazonian rain forest during CLAIRE-2001. The results from CLAIRE-2001 also showed that PBAP are mainly found in the coarse mode and that the organic aerosol which contributed about $70 \%$ to the fine mode aerosol mass is mainly originating from secondary organic aerosol formation (Graham et al., 2003b; Martin et al., 2010a). Another study from a complete different location (urban, suburban, and rural sites in Norway) that investigated the content of sugar and sugar alcohols in $\mathrm{PM}_{2.5}$ (Yttri et al., 2007), also found that the sum of sugars and sugar alcohols contributed only by a small fraction $\left(0.2 \%\right.$ to $1.0 \%$ by mass) to organic carbon in $\mathrm{PM}_{2.5}$.

In previous studies average number fractions of PBAP of about $30 \%$ (ranging between 12 and $53 \%$ ) in the submicron size range have been reported (Matthias-Maser and
Jaenicke, 1995; Jaenicke et al., 2007). It is expected that PBAP are mostly found in the upper size range of the submicron aerosol. Airborne bacteria are in the size range around $700 \mathrm{~nm}$ (Möhler et al., 2007). Thus, a number fraction of $30 \%$ would imply a mass fraction much higher than $20 \%$. Taking into account the results of this study as well as the results from Graham et al. (2003a, b) and Yttri et al. (2007), which all at least for the sugars and sugar alcohols show very little contribution to the total organic mass in $\mathrm{PM}_{2.5}$, it can be concluded that such high number fractions of up to $30 \%$ in the submicron size range may be found occasionally but are not representative.

\section{Supplementary material related to this article is available online at: http://www.atmos-chem-phys.net/11/11415/2011/ acp-11-11415-2011-supplement.pdf.}

Acknowledgements. We would like to thank the complete AMAZE08 team, but especially H. Haudeck, T. Böttger, M. Flores, and M. Brands. We also thank F. Drewnick for providing the HR-ToFAMS and for discussion on data evaluation and interpretation. Support by the LBA project and INPA (Manaus) is acknowledged. This work was funded by the Max Planck Society. SRZ was funded by the DFG Graduiertenkolleg GRK826. The USA National Science Foundation (ATM-0723582; ATM-0919189) supported QC, DKF, JLJ, and STM.

The service charges for this open access publication have been covered by the Max Planck Society.

Edited by: R. Cohen

\section{References}

Aiken, A. C., Salcedo, D., Cubison, M. J., Huffman, J. A., DeCarlo, P. F., Ulbrich, I. M., Docherty, K. S., Sueper, D., Kimmel, J. R., Worsnop, D. R., Trimborn, A., Northway, M., Stone, E. A., Schauer, J. J., Volkamer, R. M., Fortner, E., de Foy, B., Wang, J., Laskin, A., Shutthanandan, V., Zheng, J., Zhang, R., Gaffney, J., Marley, N. A., Paredes-Miranda, G., Arnott, W. P., Molina, L. T., Sosa, G., and Jimenez, J. L.: Mexico City aerosol analysis during MILAGRO using high resolution aerosol mass spectrometry at the urban supersite (T0) - Part 1: Fine particle composition and organic source apportionment, Atmos. Chem. Phys., 9, 66336653, doi:10.5194/acp-9-6633-2009, 2009.

Alfarra, M. R., Prévôt, A. S. H., Szidat, S., Sandradewi, J., Weimer, S., Lanz, V. A., Schreiber, D., Mohr, M., and Baltensperger, U.: Identification of the mass spectral signature of organic aerosols from wood burning emissions, Environ. Sci. Technol., 41, 5770 5777, doi:10.1021/es062289b, 2007.

Allan, J. D., Delia, A. E., Coe, H., Bower, K. N., Alfarra, M. R., Jimenez, J. L., Middlebrook, A. M., Drewnick, F., Onasch, T. B., Canagaratna, M. R., Jayne, J. T., and Worsnop, D. R.: A generalised method for the extraction of chemically resolved mass spectra from aerodyne aerosol mass spectrometer data, J. Aerosol. Sci., 35, 909-922, 2004. 
Beyer, H. and Walter, W.: Lehrbuch der organischen Chemie, Hirzel, Stuttgart, 1988.

Campos, M. G. R., Bogdanov, S., de Almeida-Muradian, L. B., Szczesna, T., Mancebo, Y., Frigerio, C., and Ferreira, F.: Pollen composition and standardisation of analytical methods, Journal of Apicultural Research, 47, 154-161, 2008.

Canagaratna, M. R., Jayne, J. T., Jimenez, J. L., Allan, J. D., Alfarra, M. R., Zhang, Q., Onasch, T. B., Drewnick, F., Coe, H., Middlebrook, A., Delia, A., Williams, L. R., Trimborn, A. M., Northway, M. J., DeCarlo, P. F., Kolb, C. E., Davidovits, P., and Worsnop, D. R.: Chemical and microphysical characterization of ambient aerosols with the aerodyne aerosol mass spectrometer, Mass Spectrom. Rev., 26, 185-222, 2007.

Chen, Q.: Formation of biogenic secondary organic aerosol, Ph.D. thesis, Harvard University, 2011.

Chen, Q., Farmer, D. K., Schneider, J., Zorn, S. R., Heald, C. L., Karl, T. G., Guenther, A., Allan, J. D., Robinson, N., Coe, H., Kimmel, J. R., Pauliquevis, T., Borrmann, S., Pöschl, U., Andreae, M. O., Artaxo, P., Jimenez, J. L., and Martin, S. T.: Mass spectral characterization of submicron biogenic organic particles in the Amazon Basin, Geophys. Res. Lett., 36, L20806, doi:10.1029/2009g1039880, 2009.

Cubison, M. J., Ortega, A. M., Hayes, P. L., Farmer, D. K., Day, D., Lechner, M. J., Brune, W. H., Apel, E., Diskin, G. S., Fisher, J. A., Fuelberg, H. E., Hecobian, A., Knapp, D. J., Mikoviny, T., Riemer, D., Sachse, G. W., Sessions, W., Weber, R. J., Weinheimer, A. J., Wisthaler, A., and Jimenez, J. L.: Effects of aging on organic aerosol from open biomass burning smoke in aircraft and lab studies, Atmos. Chem. Phys. Discuss., 11, 12103-12140, doi:10.5194/acpd-11-12103-2011, 2011.

Czerwieniec, G. A., Russell, S. C., Tobias, H. J., Pitesky, M. E., Fergenson, D. P., Steele, P., Srivastava, A., Horn, J. M., Frank, M., Gard, E. E., and Lebrilla, C. B.: Stable isotope labeling of entire Bacillus atrophaeus spores and vegetative cells using bioaerosol mass spectrometry, Anal. Chem., 77, 1081-1087, doi:10.1021/Ac0488098, 2005 .

DeCarlo, P. F., Kimmel, J. R., Trimborn, A., Northway, M. J., Jayne, J. T., Aiken, A. C., Gonin, M., Fuhrer, K., Horvath, T., Docherty, K. S., Worsnop, D. R., and Jimenez, J. L.: Field-deployable, high-resolution, time-of-flight aerosol mass spectrometer, Anal. Chem., 78, 8281-8289, 2006.

Deguillaume, L., Leriche, M., Amato, P., Ariya, P. A., Delort, A.M., Pöschl, U., Chaumerliac, N., Bauer, H., Flossmann, A. I., and Morris, C. E.: Microbiology and atmospheric processes: chemical interactions of primary biological aerosols, Biogeosciences, 5, 1073-1084, doi:10.5194/bg-5-1073-2008, 2008.

Diehl, K., Quick, C., Matthias-Maser, S., Mitra, S. K., and Jaenicke, R.: The ice nucleating ability of pollen - Part I: Laboratory studies in deposition and condensation freezing modes, Atmos. Res., 58, 75-87, 2001.

Diehl, K., Matthias-Maser, S., Jaenicke, R., and Mitra, S. K.: The ice nucleating ability of pollen: Part II. Laboratory studies in immersion and contact freezing modes, Atmos. Res., 61, 125133, 2002.

Diesch, J. M.: Untersuchung des Verdampfungs- und Ionisationsprozesses im Aerodyne Aerosol Massenspektrometer, Diploma Thesis, University Mainz, 2008.

Drewnick, F., Hings, S. S., DeCarlo, P., Jayne, J. T., Gonin, M., Fuhrer, K., Weimer, S., Jimenez, J. L., Demerjian, K. L.,
Borrmann, S., and Worsnop, D. R.: A new time-of-flight aerosol mass spectrometer (TOF-AMS) - Instrument description and first field deployment, Aerosol Sci. Technol., 39, 637-658, 2005.

Duplissy, J., DeCarlo, P. F., Dommen, J., Alfarra, M. R., Metzger, A., Barmpadimos, I., Prévôt, A. S. H., Weingartner, E., Tritscher, T., Gysel, M., Aiken, A. C., Jimenez, J. L., Canagaratna, M. R., Worsnop, D. R., Collins, D. R., Tomlinson, J., and Baltensperger, U.: Relating hygroscopicity and composition of organic aerosol particulate matter, Atmos. Chem. Phys., 11, 11551165, doi:10.5194/acp-11-1155-2011, 2011.

Elbert, W., Taylor, P. E., Andreae, M. O., and Pöschl, U.: Contribution of fungi to primary biogenic aerosols in the atmosphere: wet and dry discharged spores, carbohydrates, and inorganic ions, Atmos. Chem. Phys., 7, 4569-4588, doi:10.5194/acp-7-4569-2007, 2007.

Fergenson, D. P., Pitesky, M. E., Tobias, H. J., Steele, P. T., Czerwieniec, G. A., Russell, S. C., Lebrilla, C. B., Horn, J. M., Coffee, K. R., Srivastava, A., Pillai, S. P., Shih, M. T. P., Hall, H. L., Ramponi, A. J., Chang, J. T., Langlois, R. G., Estacio, P. L., Hadley, R. T., Frank, M., and Gard, E. E.: Reagentless detection and classification of individual bioaerosol particles in seconds, Anal. Chem., 76, 373-378, doi:10.1021/Ac034467e, 2004.

Fraser, M. P. and Lakshmanan, K.: Using levoglucosan as a molecular marker for the long-range transport of biomass combustion aerosols, Environ. Sci. Technol., 34, 4560-4564, doi:10.1021/es9912291, 2000.

Freutel, F.: Identifizierung charakteristischer massenspektrometrischer Marker für primäre biologische Aerosolpartikel, Diploma Thesis, University Mainz, 2009.

Graham, B., Guyon, P., Maenhaut, W., Taylor, P. E., Ebert, M., Matthias-Maser, S., Mayol-Bracero, O. L., Godoi, R. H. M., Artaxo, P., Meixner, F. X., Moura, M. A. L., Rocha, C., Van Grieken, R., Glovsky, M. M., Flagan, R. C., and Andreae, M. O.: Composition and diurnal variability of the natural Amazonian aerosol, J. Geophys. Res.-Atmos., 108, 4765, doi:10.1029/2003jd004049, 2003a

Graham, B., Guyon, P., Taylor, P. E., Artaxo, P., Maenhaut, W., Glovsky, M. M., Flagan, R. C., and Andreae, M. O.: Organic compounds present in the natural Amazonian aerosol: Characterization by gas chromatography-mass spectrometry, J. Geophys. Res.-Atmos., 108, 4766, doi:10.1029/2003jd003990, 2003b.

Hinds, W. C.: Aerosol technology - properties, behaviour, and measurements of airborne particles, 2nd ed., John Wiley \& Sons, Inc., New York, 1999.

Hoose, C., Kristjansson, J. E., and Burrows, S. M.: How important is biological ice nucleation in clouds on a global scale?, Environ. Res. Lett., 5, 024009, doi:10.1088/1748-9326/5/2/024009, 2010.

Huffman, A., Garland, R. M., and Pöschl, U.: Fluorescent biological aerosol particle concentrations and size distributions in pristine rainforest air during AMAZE-08, to be submitted to Atmos. Chem. Phys. Discuss., 2011.

Huffman, J. A., Docherty, K. S., Aiken, A. C., Cubison, M. J., U1brich, I. M., DeCarlo, P. F., Sueper, D., Jayne, J. T., Worsnop, D. R., Ziemann, P. J., and Jimenez, J. L.: Chemically-resolved aerosol volatility measurements from two megacity field studies, Atmos. Chem. Phys., 9, 7161-7182, doi:10.5194/acp-9-71612009, 2009.

Huffman, J. A., Treutlein, B., and Pöschl, U.: Fluorescent biological aerosol particle concentrations and size distributions 
measured with an Ultraviolet Aerodynamic Particle Sizer (UVAPS) in Central Europe, Atmos. Chem. Phys., 10, 3215-3233, doi:10.5194/acp-10-3215-2010, 2010.

Iannone, R., Chernoff, D. I., Pringle, A., Martin, S. T., and Bertram, A. K.: The ice nucleation ability of one of the most abundant types of fungal spores found in the atmosphere, Atmos. Chem. Phys., 11, 1191-1201, doi:10.5194/acp-11-1191-2011, 2011.

Jaenicke, R.: Abundance of cellular material and proteins in the atmosphere, Science, 308, 73-73, 2005.

Jaenicke, R., Matthias-Maser, S., and Gruber, S.: Omnipresence of biological material in the atmosphere, Environ. Chem., 4, 217220, doi:10.1071/en07021, 2007.

Jones, A. M. and Harrison, R. M.: The effects of meteorological factors on atmospheric bioaerosol concentrations - a review, Sci. Total Environ., 326, 151-180, doi:10.1016/j.scitotenv.2003.11.021, 2004.

Kroll, J. H., Smith, J. D., Che, D. L., Kessler, S. H., Worsnop, D. R., and Wilson, K. R.: Measurement of fragmentation and functionalization pathways in the heterogeneous oxidation of oxidized organic aerosol, Phys. Chem. Chem. Phys., 11, 8005-8014, doi:10.1039/B905289e, 2009.

Lee, T., Sullivan, A. P., Mack, L., Jimenez, J. L., Kreidenweis, S. M., Onasch, T. B., Worsnop, D. R., Malm, W., Wold, C. E., Hao, W. M., and Collett, J. L.: Chemical Smoke Marker Emissions During Flaming and Smoldering Phases of Laboratory Open Burning of Wildland Fuels, Aerosol Sci. Technol., 44, I-V, doi:10.1080/02786826.2010.499884, 2010.

Liu, P. S. K., Deng, R., Smith, K. A., Williams, L. R., Jayne, J. T., Canagaratna, M. R., Moore, K., Onasch, T. B., Worsnop, D. R., and Deshler, T.: Transmission efficiency of an aerodynamic focusing lens system: Comparison of model calculations and laboratory measurements for the Aerodyne Aerosol Mass Spectrometer, Aerosol Sci. Technol., 41, 721-733, doi:10.1080/02786820701422278, 2007.

Mahowald, N., Jickells, T. D., Baker, A. R., Artaxo, P., BenitezNelson, C. R., Bergametti, G., Bond, T. C., Chen, Y., Cohen, D. D., Herut, B., Kubilay, N., Losno, R., Luo, C., Maenhaut, W., McGee, K. A., Okin, G. S., Siefert, R. L., and Tsukuda, S.: Global distribution of atmospheric phosphorus sources, concentrations and deposition rates, and anthropogenic impacts, Global Biogeochem. Cy., 22, GB4026, doi:10.1029/2008gb003240, 2008.

Martin, S. T., Andreae, M. O., Althausen, D., Artaxo, P., Baars, H., Borrmann, S., Chen, Q., Farmer, D. K., Guenther, A., Gunthe, S. S., Jimenez, J. L., Karl, T., Longo, K., Manzi, A., Müller, T., Pauliquevis, T., Petters, M. D., Prenni, A. J., Pöschl, U., Rizzo, L. V., Schneider, J., Smith, J. N., Swietlicki, E., Tota, J., Wang, J., Wiedensohler, A., and Zorn, S. R.: An overview of the Amazonian Aerosol Characterization Experiment 2008 (AMAZE-08), Atmos. Chem. Phys., 10, 11415-11438, doi:10.5194/acp-1011415-2010, 2010a.

Martin, S. T., Andreae, M. O., Artaxo, P., Baumgardner, D., Chen, Q., Goldstein, A. H., Guenther, A., Heald, C. L., Mayol-Bracero, O. L., McMurry, P. H., Pauliquevis, T., Pöschl, U., Prather, K. A., Roberts, G. C., Saleska, S. R., Dias, M. A. S., Spracklen, D. V., Swietlicki, E., and Trebs, I.: Sources and properties of Amazonian aerosol particles, Rev. Geophys., 48, Rg2002, doi:10.1029/2008rg000280, 2010b.

Matsumoto, K. and Uematsu, M.: Free amino acids in marine aerosols over the western North Pacific Ocean, Atmos. Environ., 39, 2163-2170, doi:10.1016/j.atmosenv.2004.12.022, 2005.

Matthias-Maser, S. and Jaenicke, R.: The size distribution of primary biological aerosol particles with radii $>0.2 \mu \mathrm{m}$ in an urban rural influenced region, Atmos. Res., 39, 279-286, 1995.

Möhler, O., DeMott, P. J., Vali, G., and Levin, Z.: Microbiology and atmospheric processes: the role of biological particles in cloud physics, Biogeosciences, 4, 1059-1071, doi:10.5194/bg-4-10592007, 2007.

Möhler, O., Georgakopoulos, D. G., Morris, C. E., Benz, S., Ebert, V., Hunsmann, S., Saathoff, H., Schnaiter, M., and Wagner, R.: Heterogeneous ice nucleation activity of bacteria: new laboratory experiments at simulated cloud conditions, Biogeosciences, 5, 1425-1435, doi:10.5194/bg-5-1425-2008, 2008.

Mohr, C., Huffman, J. A., Cubison, M. J., Aiken, A. C., Docherty, K. S., Kimmel, J. R., Ulbrich, I. M., Hannigan, M., and Jimenez, J. L.: Characterization of Primary Organic Aerosol Emissions from Meat Cooking, Trash Burning, and Motor Vehicles with High-Resolution Aerosol Mass Spectrometry and Comparison with Ambient and Chamber Observations, Environ. Sci. Technol., 43, 2443-2449, doi:10.1021/es8011518, 2009.

Morris, C. E., Georgakopoulos, D. G., and Sands, D. C.: Ice nucleation active bacteria and their potential role in precipitation, Journal De Physique IV, 121, 87-103, doi:10.1051/jp4:2004121004, 2004.

Munk, K.: Biochemie, Zellbiologie, Ökologie, Evolution, Spektrum Akademischer Verlag, Heidelberg, 2000.

Pöschl, U., Martin, S. T., Sinha, B. W., Chen, Q., Gunthe, S. S., Huffman, J. A., Borrmann, S., Farmer, D., Garland, R. M., Helas, G., Jimenez, J. L., King, S. M., Manzi, A., Mikhailov, E., Pauliquevis, T., Petters, M. D., Prenni, A. J., Roldin, P., Rose, D., Schneider, J., Su, H., Zorn, S. R., Artaxo, P., and Andreae, M. O.: Rainforest aerosols as biogenic nuclei of clouds and precipitation in the Amazon, Science, 329, 1513-1516, 2010.

Pratt, K. A., DeMott, P. J., French, J. R., Wang, Z., Westphal, D. L., Heymsfield, A. J., Twohy, C. H., Prenni, A. J., and Prather, K. A.: In situ detection of biological particles in cloud ice-crystals, Nature Geosci., 2, 397-400, doi:10.1038/ngeo521, 2009.

Prenni, A. J., Petters, M. D., Kreidenweis, S. M., Heald, C. L., Martin, S. T., Artaxo, P., Garland, R. M., Wollny, A. G., and Pöschl, U.: Relative roles of biogenic emissions and Saharan dust as ice nuclei in the Amazon basin, Nature Geosci., 2, 401404, doi:10.1038/ngeo517, 2009.

Rogge, W. F., Hildemann, L. M., Mazurek, M. A., Cass, G. R., and Simoneit, B. R. T.: Sources of fine organic aerosol 4. Particulate abrasion products from leaf surfaces of urban plants, Environ. Sci. Technol., 27, 2700-2711, doi:10.1021/es00049a008, 1993.

Russell, S. C., Czerwieniec, G., Lebrilla, C., Tobias, H., Fergenson, D. P., Steele, P., Pitesky, M., Horn, J., Srivastava, A., Frank, M., and Gard, E. E.: Toward understanding the ionization of biomarkers from micrometer particles by bio-aerosol mass spectrometry, J. Am. Soc. Mass Spectrom., 15, 900-909, 2004.

Schneider, J., Weimer, S., Drewnick, F., Borrmann, S., Helas, G., Gwaze, P., Schmid, O., Andreae, M. O., and Kirchner, U.: Mass spectrometric analysis and aerodynamic properties of various types of combustion-related aerosol particles, Int. J. Mass Spectrom., 258, 37-49, 2006.

Silva, P. J. and K. A. Prather: Interpretation of mass spectra from organic compounds in aerosol time-of-flight mass spectrometry, 
Anal. Chem., 72, 3553-3562, 2000.

Simoneit, B. R. T., Schauer, J. J., Nolte, C. G., Oros, D. R., Elias, V. O., Fraser, M. P., Rogge, W. F., and Cass, G. R.: Levoglucosan, a tracer for cellulose in biomass burning and atmospheric particles, Atmos. Environ., 33, 173-182, 1999.

Spiteller, G.: Massenspektrometrische Strukturanalyse organischer Verbindungen, Verlag Chemie, Weinheim, 1966.

Spracklen, D. V., Carslaw, K. S., Merikanto, J., Mann, G. W., Reddington, C. L., Pickering, S., Ogren, J. A., Andrews, E., Baltensperger, U., Weingartner, E., Boy, M., Kulmala, M., Laakso, L., Lihavainen, H., Kivekäs, N., Komppula, M., Mihalopoulos, N., Kouvarakis, G., Jennings, S. G., O’Dowd, C., Birmili, W., Wiedensohler, A., Weller, R., Gras, J., Laj, P., Sellegri, K., Bonn, B., Krejci, R., Laaksonen, A., Hamed, A., Minikin, A., Harrison, R. M., Talbot, R., and Sun, J.: Explaining global surface aerosol number concentrations in terms of primary emissions and particle formation, Atmos. Chem. Phys., 10, 4775-4793, doi:10.5194/acp-10-4775-2010, 2010.

Sun, Y., Zhang, Q., Macdonald, A. M., Hayden, K., Li, S. M., Liggio, J., Liu, P. S. K., Anlauf, K. G., Leaitch, W. R., Steffen, A., Cubison, M., Worsnop, D. R., van Donkelaar, A., and Martin, R. V.: Size-resolved aerosol chemistry on Whistler Mountain, Canada with a high-resolution aerosol mass spectrometer during INTEX-B, Atmos. Chem. Phys., 9, 3095-3111, doi:10.5194/acp9-3095-2009, 2009.
Taylor, P. E., Flagan, R. C., Valenta, R., and Glovsky, M. M.: Release of allergens as respirable aerosols: A link between grass pollen and asthma, Journal of Allergy and Clinical Immunology, 109, 51-56, doi:10.1067/mai.2002.120759, 2002.

Taylor, P. E., Flagan, R. C., Miguel, A. G., Valenta, R., and Glovsky, M. M.: Birch pollen rupture and the release of aerosols of respirable allergens, Clinical and Experimental Allergy, 34, 15911596, doi:10.1111/j.1365-2222.2004.02078.x, 2004.

Tuch, T. M., Haudek, A., Müller, T., Nowak, A., Wex, H., and Wiedensohler, A.: Design and performance of an automatic regenerating adsorption aerosol dryer for continuous operation at monitoring sites, Atmos. Meas. Tech., 2, 417-422, doi:10.5194/amt-2-417-2009, 2009.

von Blohn, N., Mitra, S. K., Diehl, K., and Borrmann, S.: The ice nucleating ability of pollen: Part III: New laboratory studies in immersion and contact freezing modes including more pollen types, Atmos. Res., 78, 182-189, doi:10.1016/j.atmosres.2005.03.008, 2005.

Watson, J. D., Baker, T. A., Bell, S. P., Gann, A. A. F., Levine, M., and Losick, R. M.: Molecular biology of the gene, 6th ed., Benjamin Cummings, 2007.

Yttri, K. E., Dye, C., and Kiss, G.: Ambient aerosol concentrations of sugars and sugar-alcohols at four different sites in Norway, Atmos. Chem. Phys., 7, 4267-4279, doi:10.5194/acp-7-4267-2007, 2007. 